\title{
Dynamics and sources of suspended particulate organic matter in the Marennes-Oléron oyster farming bay: Insights from stable isotopes and microalgae ecology
}

\author{
Nathalie Malet ${ }^{\mathrm{a}, \mathrm{b},{ }^{*}}$, Pierre-Guy Sauriau ${ }^{\mathrm{a}}$, Mireille Ryckaert ${ }^{\mathrm{c}}$, Pascale Malestroit $^{\mathrm{d}}$ and Gael Guillou ${ }^{\mathrm{a}}$ \\ a Centre de Recherche sur les Ecosystèmes Littoraux Anthropisés (CNRS, IFREMER, ULR), Place du Séminaire, \\ BP 5, F-17137 L'Houmeau, France \\ b IFREMER Laboratoire Environnement Ressources Languedoc-Roussillon, Boulevard Jean Monnet, BP 171, \\ 34203 Sète, France \\ c IFREMER Laboratoire Environnement Ressources des Pertuis Charentais, Place du Séminaire, BP 7, F-17137 \\ L'Houmeau, France \\ d IFREMER Laboratoire Environnement Ressources des Pertuis Charentais, BP 133, 17390 La Tremblade, \\ France \\ *: Corresponding author : Nathalie Malet, email address : Nathalie.Malet@ifremer.fr
}

\begin{abstract}
:
The aim of this study was to distinguish between sources of the complex variety of Marennes-Oléron Bay suspended particulate organic matter (SPOM) contributing to the tropho-dynamics of the Marennes-Oléron oyster farming bay. Basic biomarkers ( $\mathrm{Chl} a, \mathrm{C} / \mathrm{N}$ and $\mathrm{POC} / \mathrm{Chl}$ a ratios), carbon and nitrogen stable isotopes from SPOM were analyzed and the microalgae community was characterized. The sampling strategy was bimonthly from March 2002 to December 2003; samples were taken from an intertidal mudflat. Four main sources contributed to the SPOM pool: terrigenous input from rivers, neritic phytoplankton, resuspended microphytobenthos and periodic inputs from intertidal Zostera noltii meadows. Seasonal fluctuations were observed in both years of the study period: (1) SPOM collected in the spring of $2002\left(\delta^{13} \mathrm{C}=-25 \%\right.$ to $-23 \%$ ) was mainly composed of fresh estuarine inputs; (2) SPOM from the summer and fall of 2002 and 2003 was predominantly neritic phytoplankton $\left(\delta^{13} \mathrm{C}=-\right.$ $22 \%$ to $-19 \%$ ); (3) SPOM from the winter of 2002 , spring of 2003 and winter of $2003\left(\delta^{13} \mathrm{C}=-21\right.$ to $-23 \%$ ) was composed of a mixture of decayed terrigenous river inputs and pelagic phytoplankton, which was predominantly resuspended microphytobenthos. In the summer of 2003-the warmest summer on record in southern France and Europe-SPOM was particularly enriched for ${ }^{13} \mathrm{C}$, with $\delta^{13} \mathrm{C}$ values ranging from $-14 \%$ to $-12 \%$. Pulses in $\delta^{13} \mathrm{C}$ values, indicative of ${ }^{13} \mathrm{C}$-enriched decaying materials, extended into the fall. These were attributed to benthic intertidal inputs, including both resuspended microphytobenthos and Z. noltii detritus. Changes in SPOM sources in Marennes-Oléron Bay may lead to differences in the quality of the trophic environment available for reared oysters.
\end{abstract}

Keywords: Marennes-Oléron Bay; suspended particulate organic matter; phytoplankton; microphytobenthos; mudflat; Zostera noltii; heatwave 


\section{Introduction}

In complex aquatic environments such as rivers (Raikow and Hamilton, 2001), lakes (Grey et al., 2001), estuaries and coastal areas (Peterson et al., 1985; Kwak and Zedler, 1997; Cloern et al., 2002), distinguishing the different organic matter (OM) sources remains an important issue. For example, in estuaries, the water column suspended OM pool is the result of mixed allochthonous sources, such as continental input, marine phytoplankton and autochthonous sources, such as coastal phytoplankton and intertidal mudflat biomass.

The stable isotopic techniques allow identification of the origin of the OM from coastal areas and estuaries (Simenstad and Wissmar, 1985; Cifuentes et al., 1996). The carbon isotopic ratios separate the ${ }^{13} \mathrm{C}$ depleted terrestrial $\mathrm{OM}$ from the more enriched marine $\mathrm{OM}$,

which explains their widespread use in the studies of estuarine food webs (Fry and Sherr, 1984; Gearing et al., 1984). In addition, studies carried out from head to the mouth of estuaries were useful to identify continental and marine end-member contributions (Shultz and Calder, 1976; Cai et al., 1988; Cifuentes et al., 1988; Middelburg and Nieuwenhuize, 1998; De Brabandere et al., 2002). However, it remains difficult to understand complex mixing processes where more than two different OM sources are involved (Cloern et al., 2002). Other parameters might be use to reduce this ambiguity and to describe the suspended particulate organic matter (SPOM) source contributions in estuaries and bays. Stable isotopes are frequently associated with $\mathrm{C} / \mathrm{N}$ ratio (Thornton and McManus, 1994; Middelburg and Nieuwenhuize, 1998; Hellings et al., 1999; Cloern et al., 2002), POC/Chl a (Cifuentes et al., 1988) or organic biomarkers (Canuel et al., 1995; Goñi et al., 2003). Description of the microalgae community of the water column might help to distinguish the different SPOM components related to benthic or pelagic compartments. The most frequently used method consists of using taxonomic discrimination (Lucas et al., 2001) considering, for instance, that all the pennate diatoms are derived from the benthic component. The microphytobenthic contribution to the water column is thus well referenced in ecosystems with large intertidal areas (Shaffer and Sullivan, 1988; de Jonge and Van Beusekom, 1992; 1995).

The Marennes-Oléron bay is one of the most important oyster farming areas in Europe with an annual oyster Crassostrea gigas production of 40000 tons (Goulletquer and Le Moine, 2002). Several earlier studies focused on the dynamics of organic matter available to cultivated oysters within the whole Bay (Héral et al., 1984; Raillard and Ménesguen, 1994; Soletchnik et al., 1998). Seston dynamics are strongly influenced by advection of the different water masses (Bacher, 1989) and by wind- and tideinduced resuspension of mudflat sediment (Héral et al., 1984; Prou et al., 1994). Consequently, autochthonous primary production of phytoplankton in the Marennes-Oléron bay is very limited in both space and time due to the high turbidity of the water column (Raillard and Ménesguen, 1994), and a considerable amount of chlorophyll-a in the water column is derived from resuspended microphytobenthos (Zurburg et al., 1994; Guarini et al., 2004). However, our knowledge about the origin of OM sources and their contribution to cultivated oyster diet is still incomplete (Riera and Richard, 1996; Richard et al., 1997; Riera and Richard, 1997; Malet et al., 2007). Riera and Richard (1996) have argued that resuspended microphytobenthos is of major importance to oysters living on intertidal mudflats. As the microphytobenthos production varies both spatially and temporally (Guarini et al., 1998), then one could expect site and time-dependant contributions of resuspended microphytobenthos to cultivated oyster diet as revealed by recent studies performed on other oyster farming areas (Decottignies et al., 2007; Riera, 2007).

The main objective of this study is to further document the temporal variability of OM sources and their contribution to the resuspended particulate organic pool of Marennes-Oléron Bay. The investigations were located on the southern mudflats of the Bay, where the dynamics of cultivated oysters stocks have been well documented (Soletchnik et al., 1998). In the present study, SPOM was characterized using multiple parameters (i.e. chloropigments, $\mathrm{C} / \mathrm{N}$ and $\mathrm{POC} / \mathrm{Chl}$ a), natural stable isotope ratios and benthic versus pelagic categories of phytoplankton species. Since seasonal and inter-annual variability related to primary production has also been demonstrated (Soletchnik et al., 1998; 2005) together with a major influence of the tidal regime on resuspension events within the Bay (Prou et al., 1994; Raillard and Ménesguen, 1994), field investigations were based on a biannual cycle and a bimonthly sampling in order to underline different time scales of the SPOM variability and precisely interpret the contribution of the different OM sources to Marennes-Oléron Bay SPOM pool. 


\section{Materials and methods}

\subsection{Study area}

Marennes-Oléron Bay is located on the French Atlantic Coast north of the Gironde estuary and is composed of $60 \%$ of intertidal mudflats (Fig. 1). Of the two rivers flowing into the bay, the Charente River was the large output of 10 to $470 \mathrm{~m}^{3} \mathrm{~s}^{-1}$, whereas the discharge of the Seudre River is much lower, ranging from 0 to $40 \mathrm{~m}^{3} \mathrm{~s}^{-1}$ (Soletchnik et al., 1998). During winter periods of high river discharge, low salinity waters also come from the Gironde estuary plume, which can enter the bay by the wide north entrance at Pertuis d'Antioche, and to a lesser extent, with the flooding tide, through the south entrance at Pertuis de Maumusson. Tidal exchange is much more important through Pertuis d'Antioche than through Pertuis de Maumusson leading to a north to south residual circulation of marine waters with a residence time varying from 5 to 10 days depending on tidal and wind conditions (Raillard and Ménesguen, 1994). The semi-diurnal tidal regime has a maximal amplitude of $6 \mathrm{~m}$. Local strong tidal currents lead to well-mixed, highly turbid waters regardless of the season (Héral et al., 1984; Zurburg et al., 1994). Wind-driven resuspension intermittently acts on intertidal muddy sediments and contributes to benthic microalgae resuspension, produced on the extensive mudflats of the bay (Guarini et al., 1998; Orvain et al., 2007).

Our study was deployed at Ronce-les-Bains, an intertidal oyster culture area (175 ha) located in the southern part of the bay (Fig. 1). The area was used for shellfish studies since the mid-1980s (Sauriau and Kang, 2000; Soletchnik et al., 2005).

\subsection{SPOM collection and analyses}

Water samples were collected twice a month from March 2002 to December 2003 at Ronce-les-Bains within the first two hours of the flood tide. Salinity using the Practical Salinity Scale and temperature were measured in situ. About 5 I of water were collected and pre-filtered with a $63 \mu \mathrm{m}$ screen to remove any zooplankton or algae debris. Suspended particulate matter (SPM) was determined after filtration through precombusted and preweighed Whatman GF/C filters and dried for $24 \mathrm{~h}$ at $60^{\circ} \mathrm{C}$. Since particulate inorganic matter (PIM) was measured after filters had been combusted for $4 \mathrm{~h}$ at $450^{\circ} \mathrm{C}$, suspended particulate organic matter (SPOM) was then determined by difference. Chlorophylla was extracted with acetone after filtration from a GF/F Whatman filter according to the method of Holm-Hansen and Riemann (1978 in Richard et al., 1997). Its concentration was determined with a Turner fluorimeter at $665 \mathrm{~nm}$. All hydrobiological parameters were determined in triplicate.

A last sample of water was filtered on a single precombusted Whatman GF/C filter and frozen $\left(-20^{\circ} \mathrm{C}\right)$ for subsequent $\mathrm{C}$ and $\mathrm{N}$ stable isotope analyses. Filters were acidified with $2 \mathrm{~N} \mathrm{HCl}$ acid vapors to remove carbonates and kept frozen until analyzed. Particulate matter was then scraped from the fiberglass filters and packed in tin cups ready for combustion. Carbon and nitrogen isotopic contents of all particulate matter samples were measured by Continuous Flow Isotope Ratio Mass Spectrometry (CF-IRMS) analysis using an IsoPrime stable isotope mass spectrometer (Micromass, Manchester, U.K.) interfaced to an elemental analyzer EuroEA3024 (Eurovector, Milan, Italy). The analytical precision for 10 consecutive measurements was $<0.15 \%$ for both $\mathrm{C}$ and $\mathrm{N}$ isotopes. Data were expressed in the standard $\delta$ notation as parts per thousand (\%) relative to the Peedee Belemnite Limestone (PDB) and atmospheric $\mathrm{N}_{2}$ for carbon and nitrogen, respectively. The stable isotopic ratio is reported as $\delta^{A} X=\left(\left(R_{\text {sample }} / R_{\text {standard }}\right)-1\right) * 10^{3}(\%)$, where $A$ is the atomic mass of the heavy stable isotope of the element $\mathrm{X}$, and $\mathrm{R}={ }^{13} \mathrm{C} /{ }^{12} \mathrm{C}$ for carbon and ${ }^{15} \mathrm{~N} /{ }^{14} \mathrm{~N}$ for nitrogen, respectively.

\subsection{Microphytobenthos and phytoplankton}

Samples of microphytobenthos assemblage were collected on the intertidal mudflat at Ronce-lesBains, by scraping the top $5 \mathrm{~mm}$ sediment surface at low tide. Samples were brought back to the laboratory where epipelic diatoms were isolated from the mud using their upward migration at low tide periods (Paterson and Crawford, 1986; Richard et al., 1997). The sediment was evenly spread in a tray to form a $1 \mathrm{~cm}$ thick layer and was covered with three $100-\mu \mathrm{m}$ nets to allow microalgae to migrate out of the sediment. Trays were placed at room ambient temperature and exposed under natural light. On the following day, epipelic diatoms were collected from the free uppermost net, which was removed after being sprayed with GF/F filtered seawater to collect motile microalgae. 
Dynamics of the phytoplankton community structure was studied at Auger, the nearest REPHY (REseau de surveillance du PHYtoplancton) station located at the south end of the Bay (Fig. 1). The REPHY network was set up by IFREMER (Institut Français de Recherche pour l'Exploitation de la MER) in 1984 to monitor changes in the phytoplankton community all along the French coast (Gailhard et al., 2002), and to record toxic events that may affect public health. According to REPHY standard protocols, living microalgae were identified and counted, and the QUADRIDGE database provides for each station the sampling date, the maximum taxonomic level of identification (from classes to species) and the corresponding microalgal density (in number of cells per I). REPHY samplings were carried out twice a month but were performed every week from May to June. Water samples were taken at $0.5-1.0 \mathrm{~m}$ with a 2.5 I NISKIN sampling bottle (Model 1010). 2.0 I were used for the taxonomic identification. Microalgal samples were preserved with lugol's solution $\left(1 \mathrm{ml} \mathrm{I}^{-1}\right)$. Ten $\mathrm{ml}$ were placed in a phytoplankton chamber for sedimentation for at least $4 \mathrm{~h}$. The organisms were identified and counted using an inverted microscope (Olympus IMT 2, Olympus, Japan), equipped with $20 \mathrm{X}$ and $40 \mathrm{X}$ lenses.

Specifically to this study, phytoplankton communities were investigated according to the microalgae affinity with the pelagic or benthic compartment (Drebes, 1974; Sournia, 1986; Ricard, 1987). The pelagic diatom community was composed mainly of Skeletonema, Chaetoceros, Leptocylindrus, Thalassiosira, Pseudonitzschia, Asterionella and dinoflagelates of Gymnodinium, Prorocentrum and Scrippsiella. The benthic diatoms were composed of Thalassionema, Fragilaria, Paralia, Plagiogramma, Navicula with smaller numbers of Raphoneis, Pleurosigma, Gyrosigma, Synedra, Triceratium, Diploneis, Thalassonema, Biddulphia, Bacillaria, Actinoptychus, Melosira and Grammatophora. Taxons were sorted in oceanic, freshwater and neritic categories.

\subsection{Statistical analyses}

The non-parametric test for association using Kendal's coefficient of rank correlation ( $\mathrm{T}$ ) was used in case of non-linear relationship between two variables and/or data known not to be normally distributed (Sokal and Rohlf, 1981, p. 601), as is the case for tidal range. Principal Component Analysis (PCA) was performed on selected variable $\left(\delta^{13} \mathrm{C}, \delta^{15} \mathrm{~N}, \mathrm{C} / \mathrm{N}\right.$, and $\mathrm{POC} / \mathrm{Chl}$ a ratios) as a seasonal groups recognition method. Correlations, regressions analysis and PCA were performed using Xlstat version 7.5 .

\section{Results}

\subsection{Environmental parameters}

In 2003, mean monthly air temperatures were higher than the monthly average over 9 months and 4 degrees higher in both June and August, whereas mean monthly air temperatures in 2002 were similar to the monthly average (Fig. 2a). The salinity ranged from 32.5 in spring to 34.5 during summer and fall, and averaged 28 in winter. The lowest salinity ca. 22 recorded in March 2002 and 2003, was the consequence of heavy rainfall during the sampling days (Fig. 2b).

The Gironde estuary drains the Dordogne and Garonne rivers for which the total discharges was relatively low in winter 2002: only 15 days with mean daily discharge $>900 \mathrm{~m}^{3} \mathrm{~s}^{-1}$ (January to March) (Fig. 2c). In contrast, river discharge $>900 \mathrm{~m}^{3} \mathrm{~s}^{-1}$ occurred for 126 days between November 2002 and March 2003. A similar seasonal cycle was observed for the Charente River, with higher discharge in winter 2003 (128 days $>50 \mathrm{~m}^{3} \mathrm{~s}^{-1}$ ) than in winter 2002 (only 37 days $>50 \mathrm{~m}^{3} \mathrm{~s}^{-1}$ ) (Fig. 2c). Charente River discharge and salinity recorded at Ronce-les-Bains were significantly correlated $(r=-0.68, p<$ $0.001, \mathrm{n}=42)$.

\subsection{Suspended particulate matter and phytoplankton}

For both years, SPM values were always higher than $100 \mathrm{mg} \mathrm{I}^{-1}$ ranging from 109 to $721 \mathrm{mg} \mathrm{I}^{-1}$. SPIM followed the same temporal pattern and ranged from 89 to $655 \mathrm{mg} \mathrm{I}^{-1}$ (Fig. 3a). Neither SPM nor SPIM were significantly correlated with tidal level over the two years $(\tau=0.019, p=0.750, n=125$ and $\tau=0.043, p=0.481, n=125$, respectively). SPOM ranged from 10 to $90 \mathrm{mg} \mathrm{I}^{-1}$ with values higher than $45 \mathrm{mg} \mathrm{l}^{-1}$ from May to November 2003. Over the two years, SPOM and SPM were highly related $(r=$ $0.72, \mathrm{p}<0.001, \mathrm{n}=125$ ). 
Chl a values ranged from 1.1 to $28.5 \mu \mathrm{g} \mathrm{I}^{-1}$ with an average of $7.5 \mu \mathrm{g} \mathrm{I}^{-1}$ in 2002, and from 0.5 to $15.8 \mu \mathrm{g} \mathrm{I}^{-1}$ with an average of $5.4 \mu \mathrm{g} \mathrm{I}^{-1}$ in 2003. Pheopigment values ranged from 3.7 to $32.5 \mu \mathrm{g} \mathrm{I}^{-1}$ with an average of $12.5 \mu \mathrm{g} \mathrm{I}^{-1}$ in 2002 and from 1.6 to $23.4 \mu \mathrm{g} \mathrm{I}^{-1}$ with an average of $9.2 \mu \mathrm{g} \mathrm{I}^{-1}$ in 2003 (Fig. 3b). The highest values occurred in spring and early summer in 2002 and in late winter and spring in 2003. Pheopiments and Chl a were highly correlated $(r=0.79, p<0.001, n=42)$. A significant Kendal's rank correlation was found between tidal range and chl a contents for both years $(\tau=0.161, p=0.010, n=125)$ but the correlation was much higher in $2003(\tau=0.391, p<0.001, n=$ 62 ) and. A significant Kendal's rank correlation was also found between tidal range and pheopigment contents for both years $(\tau=0.130, p=0.038, n=125)$. Over the two years, SPIM and pheopigments were significantly correlated $(r=0.66, p<0.001, n=125)$. SPOM and $\mathrm{Chl}$ a were significantly correlated only during the spring and early summer of 2002 i.e. from March to June $2002(r=0.74, p<$ $0.001, n=27$ ) due to short-term phytoplankton blooms (Fig. 3, 4a).

Pelagic diatoms and dinoflagelates composed most of the phytoplankton biomass and showed a high seasonality (Fig. 4). In spring, 2002 and 2003, this biomass reached 1.8 and 1.3 millions of phytoplankton cells per liter, respectively, mostly due to the Skeletonema costatum diatom blooms (Fig. $4 \mathrm{a}$, shaded area). The phytoplankton biomass was composed by 80 taxons, mainly pelagic diatoms and dinoflagelates. Among them, species were neritic, only Chaetoceros was truly an oceanic taxon and only the Euglénophyceae was a freshwater taxon.

For both years, there was one major phytoplankton bloom in spring, which was dominated by $S$. costatum and several secondary blooms during summer and fall (Fig. 4 a). In 2003, summer and fall blooms were more numerous than in 2002 and dominated by dinoflagelates. Dinoflagelates extended from April-May to September of both years, but also occurred in October 2003. Phytoplankton biomass was 1.6 times higher in 2003 than in 2002. The benthic microalgal biomass averaged monthly $7000 \pm 5000$ cells $\left.\right|^{-1}$ for those two years. They were higher in numbers than pelagic microalgae in the water column during the periods of lowest phytoplankton biomass, i.e. in JanuaryFebruary 2002, from November to January 2003 and episodically in spring and summer of 2003. During these periods, their biomass represented up to $64 \%$ of the phytoplankton biomass (Fig. 4c).

\subsection{SPOM composition}

SPOM $\delta^{13} \mathrm{C}$ showed month-to-month variability that was enlarged in 2003 compared to 2002 (Fig 5 a). The winter and spring of 2002 were characterized by SPOM $\delta^{13} \mathrm{C}$ depleted values ranging from -24 to $-23 \%$. During summer and fall, SPOM was relatively enriched in ${ }^{13} \mathrm{C}$ until reaching -21 to $-20 \%$. A slight ${ }^{13} \mathrm{C}$ depletion characterized the $2002-2003$ winter SPOM with values averaging $-22 \%$. Periodically, during summer and fall 2003 , SPOM was much enriched in ${ }^{13} \mathrm{C}$ reaching peak values of $12 \%$ (Fig. 5 a). $\delta^{13} \mathrm{C}$ data were significantly correlated with both salinity $(r=0.60, p<0.001, n=37)$ and Charente River discharge $(r=-0.49, p<0.01, n=37)$. SPOM $\delta^{15} N$ values showed much higher relative temporal variations with a ${ }^{15} \mathrm{~N}$ enrichment in spring 2002 and summers of both years. Peak values ranging from 6 to $8 \%$. From fall to winter of both years, SPOM was depleted in ${ }^{15} \mathrm{~N}$, with average values between 4 and $5 \% .{ }^{15} \mathrm{~N}$ SPOM depletion also occurred in March 2003 with values lower than $3 \%$ (Fig. 5a). $\delta^{15} \mathrm{~N}$ and pheopigment values were significantly correlated $(r=0.32, p<0.04$, $\mathrm{n}=37$ )

Changes in POC/Chl a ratio showed two different temporal patterns between 2002 and 2003 (Fig. 5 b). The POC/Chl a ratio was lower than 200 over 8 months in 2002 but reached 800 on two occasions in 2003 with several periods higher than 200. Most of POC/Chl a ratios were less than 200 in spring and around 200 in the fall of 2003.

$\mathrm{C} / \mathrm{N}$ values ranged from 6 to 11 and high C/N characterized the spring 2002 and summer and fall 2003 (Fig. 5 c). SPOM $\delta^{13} \mathrm{C}$ data, excluding the summer-fall 2003 very enriched $\delta^{13} \mathrm{C}$ values, and $\delta^{15} \mathrm{~N}$ data were highly significantly correlated with $\mathrm{C} / \mathrm{N}$ ratio $(r=-0.67, p<0.001, n=41$ and $r=0.58, p<0.001$, $\mathrm{n}=41$, respectively).

PCA performed on selected SPOM variables, $\delta$ values, $\mathrm{POC} / \mathrm{Chl}$ a and $\mathrm{C} / \mathrm{N}$ ratios (Table 1 ) allowed seasonal groups to be discriminate within our two years data set, and underlined the previously recorded correlation between $\delta$ values and C/N ratio. Scatter plot of SPOM $\delta^{13} \mathrm{C}$ versus $\delta^{15} \mathrm{~N}$ also helped in identifying these 4 groups (Fig. 6) i.e. spring 2002, summer-fall 2002, winter 2002-spring 2003-winter 2003 and summer-fall 2003 with both pelagic and benthic components (Table 1). Mean isotopic values of microphytobenthos collected during this study averaged $-14.3 \pm 1.1 \%$ for carbon and $4.3 \pm 0.8 \%$ for nitrogen. Neritic phytoplankton stable isotope values of $-21 \pm 0.4 \%$ for carbon and $5 \pm 1.0 \%$ for nitrogen was deduced from data collected from May to October 2002, where several parameters consistently indicated a major neritic phytoplankton contribution to SPOM: 1) several phytoplankton blooms (Fig. 4a, b), 2) ${ }^{13} \mathrm{C}$ enriched SPOM isotopic values (Fig. 5a), 3) POC/Chl a 
ratios below 200 (Fig. 5b), and 4) low C/N ratios (Fig. 5c). Additionally, $\delta$ values of continental inputs (Richard et al., 1997) and Zostera noltii leaves collected at Ronce-les-Bains (Kang et al., 1999) were reported on the figure 6 .

\section{Discussion}

\subsection{SPOM sources characterization}

In Marennes-Oléron Bay, allochtonous SPOM inputs are a combination of continental inputs carried by both the Charente River (Riera and Richard, 1996) and the Gironde estuary plume entering through the bay by the Maumusson Pertuis (Fontugne and Jouanneau, 1987). Our results on the correlations between $\delta^{13} \mathrm{C}$ values and salinity or river discharge

conform to this spatial feature, with depleted stable isotope ratios associated with low salinity river inputs or high river discharge. These SPOM sources are mainly of decomposed riparian vegetation with $\delta^{13} \mathrm{C}$ values between -32 and $-28 \%$ and $\delta^{15} \mathrm{~N}$ values about $6 \%$. Over the two years, the relative contribution of the continental detritic component to the SPOM was also indicated by the negative correlation between $\mathrm{C} / \mathrm{N}$ and $\delta^{13} \mathrm{C}$ values.

The river-estuary linkage also provides phytoplanktonic biomass component in spring (Ravail et al., 1988; Raillard and Ménesguen, 1994). This is corroborated by the correlation between SPOM and Chl a, which is only highly significant from March to July 2002. These blooms are dominated by Skeletonema costatum (Fig. 4a).

The freshwater phytoplankton stable isotopic composition could be estimated by measuring the freshwater dissolved inorganic carbon (DIC) $\delta^{13} \mathrm{C}$ and the associated fractionation with phytoplankton. The DIC $\delta^{13} \mathrm{C}$ of the Charente River varied between $-8 \%$ and $-13 \%$ between fall 1990 and fall 1991 (Richard et al., 1997). Considering the fractionation between DIC and phytoplankton determined by Tan and Strain (1983), equals to 22\%, the freshwater phytoplankton isotopic composition was between -35 and $-31 \%$. For instance, isotopic composition of the whole pool of continental OM carried by the river averaging $-28 \%$ for carbon and $6 \%$ for nitrogen (Richard et al., 1997) reflected a large contribution of freshwater phytoplankton. Middelburg and Nieuwenhuize (1998) reported similar OM isotopic composition, usually lower than $-26 \%$ in the Scheldt estuary. Salomons and Mook (1981) and, more recently, Thornton and McManus (1994) and Hellings et al. (1999) reported similar continental isotopic composition with $-28 \%$, -27 to $-31 \%$ and $-28 \%$ respectively.

Waters from the Atlantic ocean go into the Marennes-Oléron Bay through the Antioche and Maumusson Pertuis. However, oceanic phytoplankton inputs are scarce compared with the dominant neritic phytoplankton assemblages within the Pertuis and the Marennes-Oléron Bay because our taxonomic analysis revealed that there were only one taxon derived solely from the oceanic area, e.g. Chaetoceros sp. (Ricard, 1987).

Autochtonous Marennes-Oléron Bay inputs are characteristic of an ecosystem dominated by intertidal mudflats. It is always difficult to single out the isotopic composition of the pelagic neritic phytoplankton from the variety of SPOM sources, but during the short periods from May to October 2002 , it was possible to characterize that of local neritic phytoplankton with an average of $-21 \pm 0.4 \%$ for carbon and $5 \pm 1.0 \%$ for nitrogen (Fig. 6).

Cifuentes et al. (1988) showed similar isotopic carbon values in the Delaware estuary with $-20 \%$ as well as Middelburg and Nieuwenhuize (1998) in the upstream parts of the Scheldt Estuary.

Microphytobenthos is also an important autochtonous source biomass throughout the year in Marennes-Oléron Bay (Guarini et al., 1998; Sauriau and Kang, 2000). Values of the isotopic composition of microphytobenthos, recorded in this study, was enriched in ${ }^{13} \mathrm{C}(-12.9$ to $-16.5 \%)$ but similar to values reported by Haines (1976), Riera and Richard (1996) and Kang et al. (1999). Several studies have suggested that the microphytobenthic biomass contributes greatly to the phytoplanktonic biomass of the Marennes-Oléron bay (Guarini et al., 2004). Over our two year study, microphytobenthos biomass was present in the water column and episodically exceed the entire pelagic phytoplankton biomass (Fig. 4b, c). Benthic microalgae are resuspended by wind-driven waves and tidal currents together with superficial sediments (Orvain et al., 2007) explaining the positive correlation between SPIM and pheopigments.

The carbon and nitrogen isotopic composition of Spartina $s p$. is close to those of microphytobenthos (Riera et al., 1999), but their spatial distribution is restricted to small spots mainly located on the eastern shores of Marennes-Oléron Bay (see map in Pigeot et al., 2006). This implies a negligible or 
at least a very low contribution of upper plants to the SPOM pool at Ronce-les-Bains. The large seagrass, Zostera noltii, meadows that cover the sandy-mud intertidal fringe of Oléron Island (Pigeot et al., 2006) together with smaller spots also present on southern mudflats of the bay (Kang et al., 1999) may contribute to the SPOM pool. The Zostera noltii isotopic composition is highly enriched in both ${ }^{13} \mathrm{C}$ with $\delta^{13} \mathrm{C}$ of $-11 \%$ and ${ }^{15} \mathrm{~N}$ with $\delta^{15} \mathrm{~N}$ of $10 \%$ (Fig. 6), and these values are in accordance with previous results (Kang et al., 1999; Boschker et al., 2000).

\subsection{Temporal changes in SPOM}

Isotopic composition of the SPOM integrates information concerning the mixing of material from various sources of origin and level of degradation. The spring 2002 (Table 1, Fig. 6) was characterized by a SPOM depleted in ${ }^{13} \mathrm{C}$ and enriched in ${ }^{15} \mathrm{~N}$ with a high $\mathrm{C} / \mathrm{N}$ ratio suggesting continental inputs (Middelburg and Nieuwenhuize, 1998). POC/Chl a ratios below 100 mean that SPOM was composed mainly of fresh material, a view reinforced by the highly significant correlation between SPOM and Chl a from March to June 2002 pelagic blooms. We can conclude that SPOM was composed of Charente estuarine phytoplankton. During that period, it is improbable that Gironde estuarine phytoplankton contributed to the OM pool of Marennes-Oléron Bay due to the low and decreasing Gironde discharge (Fig. 2c).

During the summer-fall of both 2002 and 2003 (Table 1, Fig. 6), the SPOM isotopic composition was enriched in ${ }^{13} \mathrm{C}$ and depleted in ${ }^{15} \mathrm{~N}$ with a POC/Chl a below 200, which all together suggest a fresh neritic phytoplankton contribution. Additionally, over this time frame, the pelagic phytoplankton abundance in the water column was largely above that of microphytobenthos and dominated by successive blooms of dinoflagellates and diatoms (Fig. 4b, c).

During Winter 2002-spring 2003 and winter 2003 (Table 1, Fig. 6), the SPOM isotopic composition was depleted in ${ }^{13} \mathrm{C}$ due to elevated continental inputs resulting from high both Charente and Gironde river discharges (Fig. 2c). The POC/Chl a ratio was highly variable suggesting pulse in contribution of decomposed continental OM. An elevated $\mathrm{POC} / \mathrm{Chl}$ a ratio might result from the degradation of organic matter if the $\mathrm{Chl} \mathrm{a}$ is decomposed at a greater rate than the total organic carbon (Cifuentes et al., 1988). If degradation has occurred, a correspondingly low $\mathrm{C} / \mathrm{N}$ ratio implies that either the original material is mostly planktonic or the degraded material had been colonized by bacteria. $\delta^{15} \mathrm{~N}$ values were also depleted ranging from 2.3 to $4.9 \%$. These values are typically associated with isotopic composition of terrestrial decomposed material (Mariotti et al., 1984; Middelburg and Nieuwenhuize, 1998). The phytoplankton contribution to the OM pool was mainly through resuspended microphytobenthos accounting for $26.3 \pm 20.6 \%$ of total phytoplanktonic biomass. Guarini et al. (2004) showed the higher contribution of the microphytobenthos to SPOM in Marennes-Oléron Bay, during winter period may reach up 89\%. However, these values appeared as overestimates possibly due to improper taxonomic discrimination considering all pennate diatoms as microphytobenthos.

Seasonal trends on hydrological variables such as nutrients and chloropigments were described in Marennes-Oléron Bay over 17 years of bimonthly measurements made on channel waters (Soletchnik et al., 1998). Results from the present study do not fully match the expected trend in chloropigments during the summer and fall of 2003 (Table 1, Fig. 6). Although chloropigments concentrations during summer and fall hardly differed between 2002 and 2003 (Fig. 3b), other biomarkers are indicative of qualitative changes in the relative importance of source contributions. $\delta^{13} \mathrm{C}$ values, recorded in intertidal mudflat of southern part of Marennes-Oléron Bay, were much more highly enriched than previously recorded in the Bay. For instance, Kang et al. (1999) reported slightly variable values averaging $-22 \%$ in the water column at Ronce-les-Bains, as well as Riera and Richard (1997), with values ranging from -22 to $-19.3 \%$ in the Charente River channel. The high $\delta^{13} \mathrm{C}$ values recorded in this study were the evidence of an much more highly enriched ${ }^{13} \mathrm{C}$ OM source. High total suspended particulate matter and POC/Chl a ratio above 200 indicates resuspended sediment in the water column and consequently similarly resuspended microphytobenthos. The microphytobenthos contribution $\left(\delta^{13} \mathrm{C}=-14.3 \%\right.$; $\delta^{15} \mathrm{~N}=4.3 \%$ ) cannot however explain all of the enriched $\delta^{13} \mathrm{C}$ values that ranged from -14 to $-12 \%$. According to an in situ experiment of Fenton and Ritz (1988) on macroalgae, the decomposition process can induce 0.5 to $1.2 \%{ }^{13} \mathrm{C}$ enrichment suggesting a contribution of microphytobenthos-degraded material. Additionally, as OM degradation is a temperature dependant process, it is likely that microphytobenthos decomposition was higher in 2003 than in 2002, due to the occurrence of an unusual heatwave during the summer 2003, which is known as the warmest summer on record in southern France and Europe (Schär et al., 2004; Rebetez et al., 2006). However, the contribution of microphytobenthos-degraded material does not explain the observed enrichment $\delta^{15} \mathrm{~N}$ from 5.3 to $6.5 \%$. We suggest that the Zostera noltii meadows occurring on 
the intertidal fringe of both Oléron Island and southern mudflats of Marenne-Oléron Bay, with its characteristic isotopic compositions of $\delta^{13} \mathrm{C}=-11 \%$ and $\delta^{15} \mathrm{~N}=8 \%$, may be at least partly responsible for the SPOM enrichment. Hemminga and Mateo (1996) and Lepoint et al. (2004) have also reported Zostera $s p . \quad \delta^{13} \mathrm{C}$ isotopic average of $-10 \%$. Additionally, during summer periods (Vizzini et al., 2003) or high light intensity (Abal et al., 1994; Grice et al., 1996) the $\delta^{13} \mathrm{C}$ isotopic composition of Zostera sp. became enriched due to higher carbon incorporation and primary production. The heatwave of 2003 that was particularly noticeable in June and August 2003 in southern France (Schär et al., 2004; Rebetez et al., 2006) may have induced both enhanced primary production in early summer and secondly, in mid summer, higher degradation rates of Zostera meadow, which consequently highly participated to the SPOM.

\subsection{Implication of temporal change in food quality to cultivated oysters}

Numerous studies on the Marennes-Oléron Bay have referred to the trophic linkage between the SPOM of the water column and reared oysters, through investigations on hydrology (e.g. Héral et al., 1984; Ravail et al., 1988; Soletchnik et al., 1998), mechanisms of oyster nutrition (Barillé et al., 1997), models of trophic capacity (Bacher, 1989; Raillard and Ménesguen, 1994) and dynamics of oyster stocks (Goulletquer and Le Moine, 2002; Soletchnik et al., 2005). Following Richard et al. (1997) and Kang et al. (1999), the present study provides new information on the chemical quality of sources, with both origin and end-member contributions, available to reared oysters within the Bay. In spring, available sources depended on the strength of continental nutrient inputs and associated estuarine microalgae production. Together with summer neritic phytoplankton biomass, they provide energy for oyster growth and gonad development (Bacher, 1989; Raillard and Ménesguen, 1994). The resuspended microphytobenthos present over the year must contribute largely to the oyster diet, as consistently reported by Malet et al. (2007), in the same studied site in 2002, with a preferential incorporation of ${ }^{13} \mathrm{C}$ enriched carbon in oyster tissues during fall and winter. The present study also underlines the question of the relationship between the oyster physiological cycle (i.e. resting period, gametogenic development, spawning, energy storage) and the quality of available food sources. In addition, important changes in the material of the SPOM create spatial heterogeneities for different parts of Marennes-Oléron Bay. Changes in resuspended benthic intertidal biomass (e.g. microphytobenthos versus Zostera-derived SPOM) can led to differences in the quality of the trophic environment for reared oysters and in turn to differences in oyster growth, survival and production. This major issue is however beyond the scope of this study and needs further investigations.

\section{Conclusion}

Temporal variability in chloropigments and associated biomarkers, $\delta^{13} \mathrm{C}$ and $\delta^{15} \mathrm{~N}$ ratios together with microalgae ecology, provided consistent information on the origin and mixing of the OM sources collected from an intertidal mudflat in Marennes-Oléron Bay. One unexpected result of the present study relates to the difference in $\delta^{13} \mathrm{C}$ of SPOM between the summer-fall of 2002 and 2003. The more enriched $\delta^{13} \mathrm{C}$ values recorded in 2003 were attributed to decaying intertidal inputs with both resuspended decomposed microphytobenthos and Zostera noltii detritus. During summer and fall of 2003, enhancement of decomposition process, acting on benthic primary producers living on mudflats regularly exposed to air and sun drying, is consistent with the fact that the summer 2003 was one of the warmest on record across southern France (Schär et al., 2004; Rebetez et al., 2006). During the heatwave of 2003, high participation of decomposed material to the SPOM may have led to the modification or alteration of the quality of $\mathrm{OM}$ available to oysters. Finally, this study highlights the needs to further studies to better understand the influence of fluctuations in food source quality on reared oysters not only in the context of carrying capacity (Bacher, 1989; Héral, 1993) and trophic competition, but also in the context of global warming.

\section{Acknowledgments}

The authors thank F. Mornet and M. Breret for chlorophyll-a analysis and water sample filtration. Thanks are also due to Pr. McManus, P. Soletchnik and an anonymous reviewer for their valuable 
comments on the manuscript. This research was funded by CNRS, IFREMER and Région PoitouCharentes. N. Malet was supported by a PhD grant from Conseil Régional de la Charente-Maritime.

\section{References}

Abal, E.G., Loneragan, N., Bowen, P., Perry, C.J., Udy, J.W., Dennison, W.C. 1994. Responses of the seagrass Zostera capricorni Aschers, to light intensity. Journal of Experimental Marine Biology and Ecology 178, 113-129.

Bacher, C. 1989. Capacité trophique du bassin de Marennes-Oléron : couplage d'un modèle de transport particulaire et d'un modèle de croissance de l'huître Crassostrea gigas. Aquatic Living Resources 2, 199-214.

Barillé, L., Prou, J., Héral, M., Razet, D. 1997. Effect of high natural seston concentration on the feeding, selection and absorption of the oyster Crassostrea gigas (Thunberg). Journal of Experimental Marine Biology and Ecology 212, 149-172.

Boschker, H.T.S., Wielemaker, A., Schaub, B.E.M., Holmer, M. 2000. Limited coupling of macrophyte production and bacterial carbon cycling in the sediments of Zostera spp. meadows. Marine Ecology Progress Series 203, 181-189.

Cai, D.-L., Tan, F.-C., Edmond, J.M. 1988. Sources and transport of particulate organic carbon in the Amazon river and estuary. Estuarine, Coastal and Shelf Science 26, 1-14.

Canuel, E.A., Cloern, J.E., Ringelberg, D.B., Guckert, J.B., Rau, G.H. 1995. Molecular and isotopic tracers used to examine sources of organic matter and its incorporation into the food webs of San Francisco Bay. Limnology and Oceanography 40, 67-81.

Cifuentes, L.A., Sharp, J.H., Fogel, M.L. 1988. Stable carbon and nitrogen isotope biogeochemistry in the Delaware estuary. Limnology and Oceanography 33, 1102-1115.

Cifuentes, L.A., Coffin, R.B., Solorzano, L., Cardenas, W., Espinoza, J., Twilley, R.R. 1996. Isotopic and elemental variations of carbon and nitrogen in a mangrove estuary. Estuarine, Coastal and Shelf Science 43, 781-800.

Cloern, J.E., Canuel, E.A., Harris, D. 2002. Stable carbon and nitrogen isotope composition of aquatic and terrestrial plants of the San Francisco Bay estuarine system. Limnology and Oceanography 47, 713-729.

De Brabandere, L., Dehairs, F., Van Damme, S., Brion, N., Meire, P., Daro, N. 2002. $\delta^{15} \mathrm{~N}$ and $\delta^{13} \mathrm{C}$ dynamics of suspended organic matter in freshwater and brackish waters of the Scheldt estuary. Journal of Sea Research 48, 1-15.

de Jonge, V.N., Van Beusekom, J.E.E. 1992. Contribution of resuspended microphytobenthos to total phytoplankton in the Ems Estuary and its possible role for grazers. Netherlands Journal of Sea Research 30, 91-105.

de Jonge, V.N., Van Beusekom, J.E.E. 1995. Wind- and tide-induced resuspension of sediment and microphytobenthos from tidal flats in the Ems estuary. Limnology and Oceanography 40, 766-778.

Decottignies, P., Beninger, P.G., Rincé, Y., Robins, R.J., Riera, P. 2007. Exploitation of natural food sources by two sympatric, invasive suspension feeders: Crassostrea gigas and Crepidula fornicata. Marine Ecology Progress Series 334, 179-192.

Drebes, G. 1974. Marines Phytoplankton, Georg Thieme Verlag, Stuttgart, 186 p.

Fenton, G.E., Ritz, D.A. 1988. Changes in carbon and hydrogen stable isotope ratios of macroalgae and seagrass during decomposition. Estuarine, Coastal and Shelf Science 26, 429-436.

Fontugne, M.R., Jouanneau, J.M. 1987. Modulation of the particulate organic carbon flux to the ocean by a macrotidal estuary: evidence from measurements of carbon isotopes in organic matter from the Gironde system. Estuarine, Coastal and Shelf Science 24, 377-387.

Fry, B., Sherr, E.B. 1984. $\delta^{13} \mathrm{C}$ measurements as indicators of carbon flow in marine and freshwater ecosystems. Contribution in Marine Science 27, 13-47.

Gailhard, I., Gros, P., Durbec, J.P., Beliaeff, B., Belin, C., Nézan, E., Lassus, P. 2002. Variability patterns of microphytoplankton communities along the French coasts. Marine Ecology Progress Series 242, 39-50.

Gearing, J.N., Gearing, P.J., Rudnick, D.T., Requejo, A.G., Hutchins, M.J. 1984. Isotopic variability of organic carbon in a phytoplankton-based, temperate estuary. Geochimica et Cosmochimica Acta 48, 1089-1098.

Goñi, M.A., Teixeira, M.J., Perkey, D.W. 2003. Sources and distribution of organic matter in a riverdominated estuary (Winyah Bay, SC, USA). Estuarine, Coastal and Shelf Science 57, 1023-1048. 
Goulletquer, P., Le Moine, O. 2002. Shellfish farming and coastal zone management (CZM) development in the Marennes-Oléron Bay and Charentais Sounds (Charente Maritime, France): a review of recent developments. Aquaculture International 10, 507-525.

Grey, J., Jones, R.I., Sleep, D. 2001. Seasonal changes in the importance of the source of organic matter to the diet of zooplanton in Loch Ness, as indicated by stable isotope analysis. Limnology and Oceanography 46, 505-513.

Grice, A.M., Loneragan, N.R., Dennison, W.C. 1996. Light intensity and the interaction between physiology, morphology and stable isotope ratios in five species of seagrass. Journal of Experimental Marine Biology and Ecology 195, 91-110.

Guarini, J.-M., Blanchard, G.F., Bacher, C., Gros, P., Riera, P., Richard, P., Gouleau, D., Galois, R., Prou, J., Sauriau, P.-G. 1998. Dynamics of spatial patterns of microphytobenthic biomass: inferences from a geostatistical analysis of two comprehensive surveys in Marennes-Oléron Bay (France). Marine Ecology Progress Series 166, 131-141.

Guarini, J.-M., Gros, P., Blanchard, G.F., Richard, P., Fillon, A. 2004. Benthic contribution to pelagic microalgal communities in two semi-enclosed, european type littoral ecosystems (Marennes-Oléron Bay and Aiguillon Bay, France). Journal of Sea Research 52, 241-258.

Haines, E.B. 1976. Relation between the stable carbon isotope composition of fiddler crabs, plants, and soils in a salt marsh. Limnology and Oceanography 21, 880-883.

Hellings, L., Dehairs, F., Tackx, M., Keppens, E., Baeyens, W. 1999. Origin and fate of organic carbon in the freshwater part of the Scheldt Estuary as traced by stable isotope composition. Biogeochemistry 47, 167-186.

Hemminga, M.A., Mateo, M.A. 1996. Stable carbon isotopes in seagrass: variability in ratios and use in ecological studies. Marine Ecology Progress Series 140, 285-298.

Héral, M., Razet, D., Deslous-Paoli, J.M., Manaud, F., Truquet, I., Garnier, J. 1984. Hydrobiologie du bassin de Marennes-Oléron. Résultats du Réseau National d'Observation : 1977 à 1981. Annales de la Société des Sciences Naturelles de la Charente-Maritime 7, 259-277.

Héral, M. 1993. Why carrying capacity models are useful tools for management of bivalve mollusc culture. In Dame R.F. (ed.) Bivalve filter feeders in estuarine and coastal ecosystem processes. Springer-Verlag, Berlin pp 455-476.

Kang, C.K., Sauriau, P.-G., Richard, P., Blanchard, G.F. 1999. Food sources of the infaunal suspension-feeding bivalve Cerastoderma edule in a muddy sandflat of Marennes-Oléron Bay, as determined by analyses of carbon and nitrogen stable isotopes. Marine Ecology Progress Series 187, 147-158.

Kwak, T.J., Zedler, J.B. 1997. Food web analysis of southern California coastal wetlands using multiple stable isotopes. Oecologia 110, 262-277.

Lepoint, G., Dauby, P., Gobert, S. 2004. Applications of C and N stable isotopes to ecological and environmental studies in seagrass ecosystems. Marine Pollution Bulletin 49, 887-891.

Lucas, C.H., Banham, C., Holligan, P.M. 2001. Benthic-pelagic exchange of microalgae at a tidal flat. 2. Taxonomic analysis. Marine Ecology Progress Series 212, 39-52.

Malet, N., Sauriau, P.-G., Faury, N., Soletchnik, P., Guillou, G. 2007. Effect of seasonal variation in trophic conditions and the gametogenic cycle on $\delta^{13} \mathrm{C}$ and $\delta^{15} \mathrm{~N}$ levels of diploid and triploid Pacific oysters Crassostrea gigas. Marine Ecology Progress Series 346, 203-217.

Mariotti, A., Lancelot, C., Billen, G. 1984. Natural isotopic composition of nitrogen as a tracer of origin for suspended organic matter in the Scheldt estuary. Geochimica et Cosmochimica Acta 48, 549-555.

Middelburg, J.J., Nieuwenhuize, J. 1998. Carbon and nitrogen stable isotopes in suspended matter and sediments from the Schelde Estuary. Marine Chemistry 60, 217-225.

Orvain, F., Sauriau, P.-G., Le Hir, P., Guillou, G., Cann, P., Paillard, M. 2007. Spatio-temporal variations in intertidal mudflat erodability: Marennes-Oléron Bay, western France. Continental Shelf Research 27, 1153-1173.

Paterson, D.M., Crawford, R.M. 1986. The structure of benthic diatom assemblages: a preliminary account of the use and evaluation of low-temperature scanning electron microscopy. Journal of Experimental Marine Biology and Ecology 95, 279-289.

Peterson, B.J., Howarth, R.W., Garrit, R.H. 1985. Multiple stable isotopes used to trace the flow of organic matter in estuarine food webs. Science 227, 1361-1363.

Pigeot, J., Miramand, P., Guyot, T., Sauriau, P.-G., Fichet, D., Le Moine, O., Huet, V. 2006. Cadmium pathways in an exploited intertidal ecosystem with chronic Cd inputs (Marennes-Oléron, Atlantic coast, France). Marine Ecology Progress Series 101-114.

Prou, J., Barillé, L., Héral, M., Ratiskol, J., Soletchnik, P., Bougrier, S., Razet, D., Geairon, P. 1994. Influence du cycle semi-diurne et vives-eaux mortes-eaux sur la disponibilité du matériel particulaire et son utilisation par une population de Mytilus edulis. Haliotis 23, 139-153. 
Raikow, D.F., Hamilton, S.K. 2001. Bivalve diets in a midwestern U.S. stream: a stable isotope enrichment study. Limnology and Oceanography 46, 514-522.

Raillard, O., Ménesguen, A. 1994. An ecosystem box model for estimating the carrying capacity of a macrotidal shellfish system. Marine Ecology Progress Series 115, 117-130.

Ravail, B., Héral, M., Maestrini, S., Robert, J.-M. 1988. Incidence du débit de la Charente sur la capacité biotique du bassin ostréicole de Marennes-Oléron. Journal de Recherche Océanographique $13,48-52$.

Rebetez, M., Mayer, H., Dupont, O., Schindler, D., Gartner, K., Kropp, J.P., Menzel, A. 2006. Heat and drought 2003 in Europe: a climate synthesis. Annals of Forest Science 63, 569-577.

Ricard, M. 1987. Atlas du phytoplancton marin : diatomophycées, Edition du CNRS, Paris, 297.

Richard, P., Riera, P., Galois, R. 1997. Temporal variations in the chemical and carbon isotope compositions of marine and terrestrial organic inputs in the Bay of Marennes-Oléron, France. Journal of Coastal Research 13, 879-889.

Riera, P., Richard, P. 1996. Isotopic determination of food sources of Crassostrea gigas along a trophic gradient in the estuarine bay of Marennes-Oléron. Estuarine, Coastal and Shelf Science 42, 347-360.

Riera, P., Richard, P. 1997. Temporal variation of $\delta^{13} \mathrm{C}$ in particulate organic matter and oyster Crassostrea gigas in Marennes-Oléron Bay (France): effect of freshwater inflow. Marine Ecology Progress Series 147, 105-115.

Riera, P., Stal, L.J., Nieuwenhuize, J., Richard, P., Blanchard, G.F., Gentil, F. 1999. Determination of food sources for benthic invertebrates in a salt marsh (Aiguillon Bay, France) by carbon and nitrogen stable isotopes: importance of locally produced sources. Marine Ecology Progress Series 187, 301307.

Riera, P. 2007. Trophic subsidies of Crassostrea gigas, Mytilus edulis and Crepidula fornicata in the Bay of Mont Saint Michel (France): a $\delta^{13} \mathrm{C}$ and $\delta^{15} \mathrm{~N}$ investigation. Estuarine, Coastal and Shelf Science 72, 33-41.

Salomons, W., Mook, W.G. 1981. Field observations of the isotopic composition of particulate organic carbon in the southern North Sea and adjacent estuaries. Marine Geology 41, 11-20.

Sauriau, P.-G., Kang, C.K. 2000. Stable isotope evidence of benthic microalgae-based growth and secondary production in the suspension feeder Cerastoderma edule (Mollusca, Bivalvia) in the Marenne-Oléron Bay. Hydrobiologia 440, 317-329.

Schär, C., Vidale, P.L., Lüthi, D., Frei, D., Häberli, C., Liniger, M.A., Appenzeller, C. 2004. The role of increasing temperature variability in Europe summer heatwaves. Nature 427, 332-336.

Shaffer, G.P., Sullivan, M.J. 1988. Water column productivity attributable to displaced benthic diatoms in well-miwed shallow estuaries. Journal of Phycology 24, 132-140.

Shultz, J.D., Calder, J.A. 1976. Organic carbon ${ }^{13} \mathrm{C}^{12} \mathrm{C}$ variations in estuarine sediments. Geochimica et Cosmochimica Acta 40, 381-385.

Simenstad, C.A., Wissmar, R.C. 1985. $\delta^{13} \mathrm{C}$ evidence of the origins and fates of organic carbon in estuarine and nearshore food webs. Marine Ecology Progress Series 22, 141-152.

Sokal, R.R., Rohlf, F.J. 1981. Biometry. The principles and practice of statistics in biological research, Freeman, W.H. and Co., NJ.

Soletchnik, P., Faury, N., Razet, D., Goulletquer, P. 1998. Hydrobiology of the Marennes-Oléron bay. Seasonal indices and analysis of trends from 1978 to 1995. Hydrobiologia 386, 131-146.

Soletchnik, P., Faury, N., Goulletquer, P. 2005. Seasonal changes in carbohydrate metabolism and its relationship with summer mortality of Pacific oyster Crassostrea gigas (Thunberg) in Marennes-Oléron bay (France). Aquaculture 252, 328-338.

Soletchnik, P., Lambert, C., Costil, K. 2005. Summer mortality of Crassostrea gigas (Thunberg) in relation to environmental rearing conditions. Journal of Shellfish Research 24, 197-207.

Sournia, A. 1986. Atlas du phytoplancton marin, Edition du CNRS, Paris.

Tan, F.C., Strain, P.M. 1983. Sources, sinks and distribution of organic carbon in the St. Lawrence Estuary, Canada. Geochimica et Cosmochimica Acta 47, 125-132.

Thornton, S.F., McManus, J. 1994. Application of organic carbon and nitrogen stable isotope and C/N ratios as source indicators of organic matter provenance in estuarine systems: evidence from the Tay Estuary, Scotland. Estuarine, Coastal and Shelf Science 38, 219-233.

Vizzini, S., Sara, G., Mateo, M.A., Mazzola, A. 2003. $\delta^{13} \mathrm{C}$ and $\delta^{15} \mathrm{~N}$ variability in Posidonia oceanica associated with seasonality and plant fraction. Aquatic Botany 76, 195-202.

Zurburg, W., Smaal, A.A.D., Héral, M., Dankers, N. 1994. Seston dynamics and bivalve feeding in the bay of Marennes-Oléron (France). Netherlands Journal of Aquatic Ecology 28, 459-466. 


\section{Tables}

Table 1: Seasonal groups over the two years 2002 and 2003 revealed by PCA analysis on SPOM stable isotope compositions, $\mathrm{C} / \mathrm{N}$ and $\mathrm{POC} / \mathrm{Chl}$ a ratios (mean $\pm \mathrm{SD}, \mathrm{n}=$ number of values).

\begin{tabular}{|c|c|c|c|c|c|c|}
\hline & & $\mathrm{n}$ & $\delta^{13} \mathrm{C}(\%)$ & $\delta^{15} \mathrm{~N}(\%)$ & $\mathrm{C} / \mathrm{N}$ & POC/Chl a \\
\hline \multicolumn{2}{|l|}{ spring 2002} & 5 & $-23.2 \pm 0.4$ & $6.7 \pm 0.9$ & $10.4 \pm 0.4$ & $54.4 \pm 13.0$ \\
\hline \multicolumn{2}{|l|}{ summer-fall 2002} & 13 & $-20.9 \pm 0.4$ & $5.1 \pm 1.0$ & $7.5 \pm 0.7$ & $101.5 \pm 66.5$ \\
\hline \multicolumn{2}{|c|}{ winter 2002-spring 2003-winter 2003} & 15 & $-21.8 \pm 0.4$ & $4.1 \pm 0.8$ & $6.9 \pm 0.5$ & $250.3 \pm 238.2$ \\
\hline \multirow{2}{*}{ summer-fall 2003} & Pelagic component & 4 & $-20.5 \pm 0.6$ & $5.1 \pm 0.3$ & $6.5 \pm 0.2$ & $238.4 \pm 69.3$ \\
\hline & Benthic component & 4 & $-13.3 \pm 0.5$ & $5.7 \pm 0.4$ & $10.4 \pm 0.7$ & $277.5 \pm 91.1$ \\
\hline
\end{tabular}




\section{Figures}

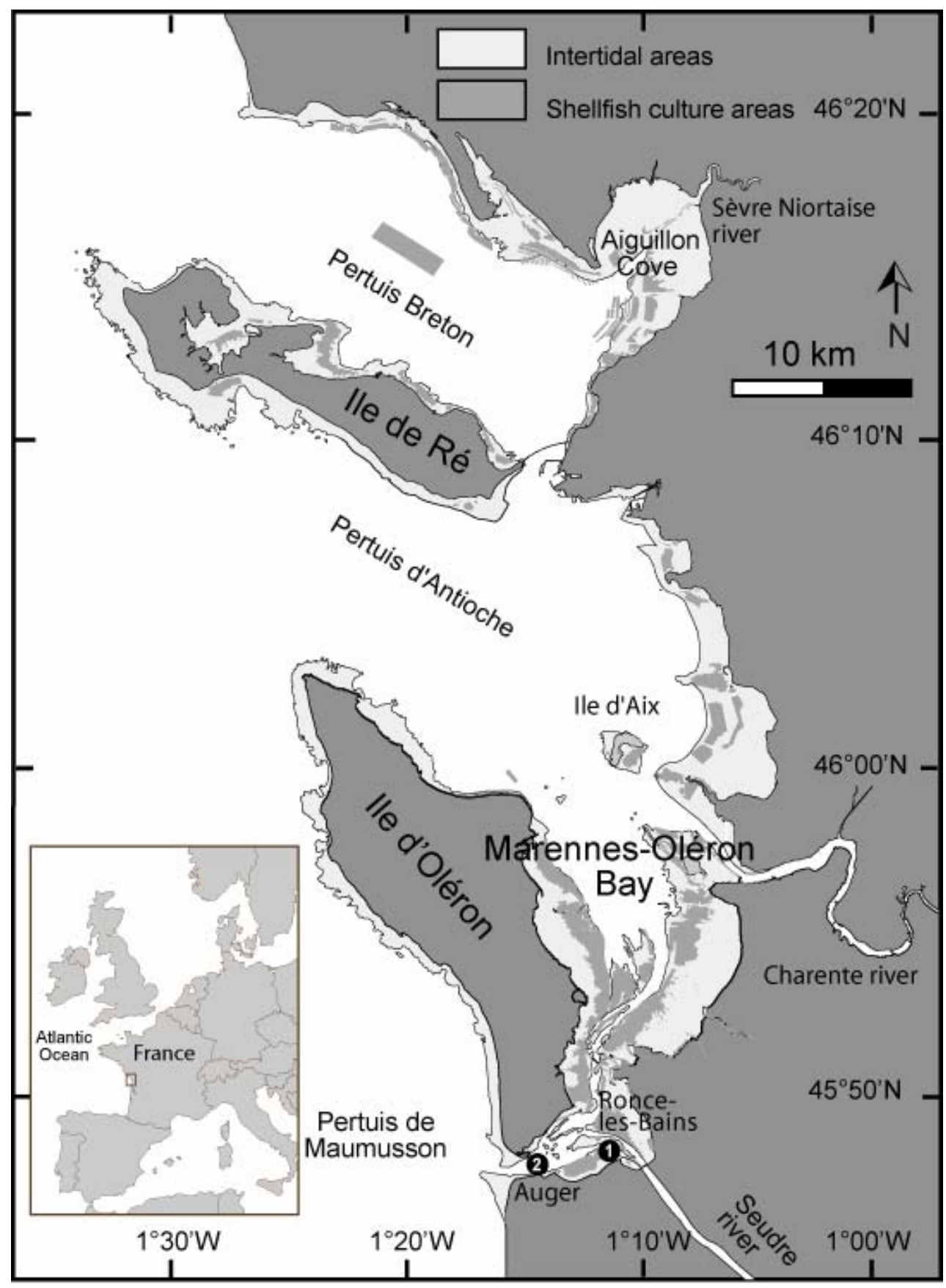

Figure 1. Map of the Marennes-Oléron Bay (France) with location of the sampling stations: (1) Ronceles-Bains mudflat and (2) Auger (REPHY) sampling station. Oyster leasing grounds (mid-grey shaded) and interdidal areas (grey shaded). 

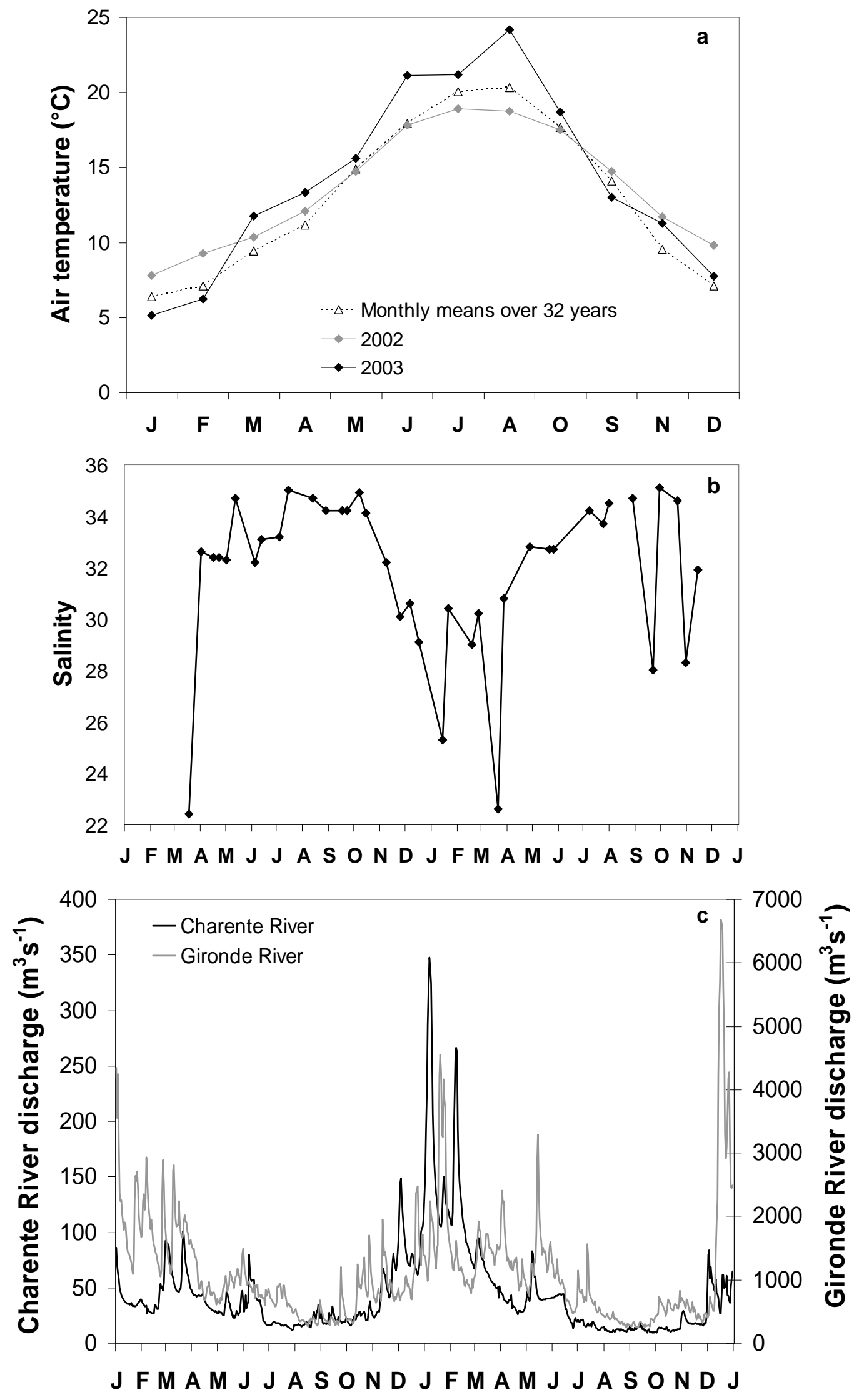

Figure 2. Temporal variation of montly means of a) air temperature in $2002(\bullet), 2003(\bullet)$ and means over 32 years $(\triangle)$ (Météo France data at La Rochelle "Le Bout Blanc"), (b) salinity from March 2002 to 
December 2003 and (c) Charente and Gironde river discharges $\left(\mathrm{m}^{3} \mathrm{~s}^{-1}\right)$ from January 2002 to January 2004.
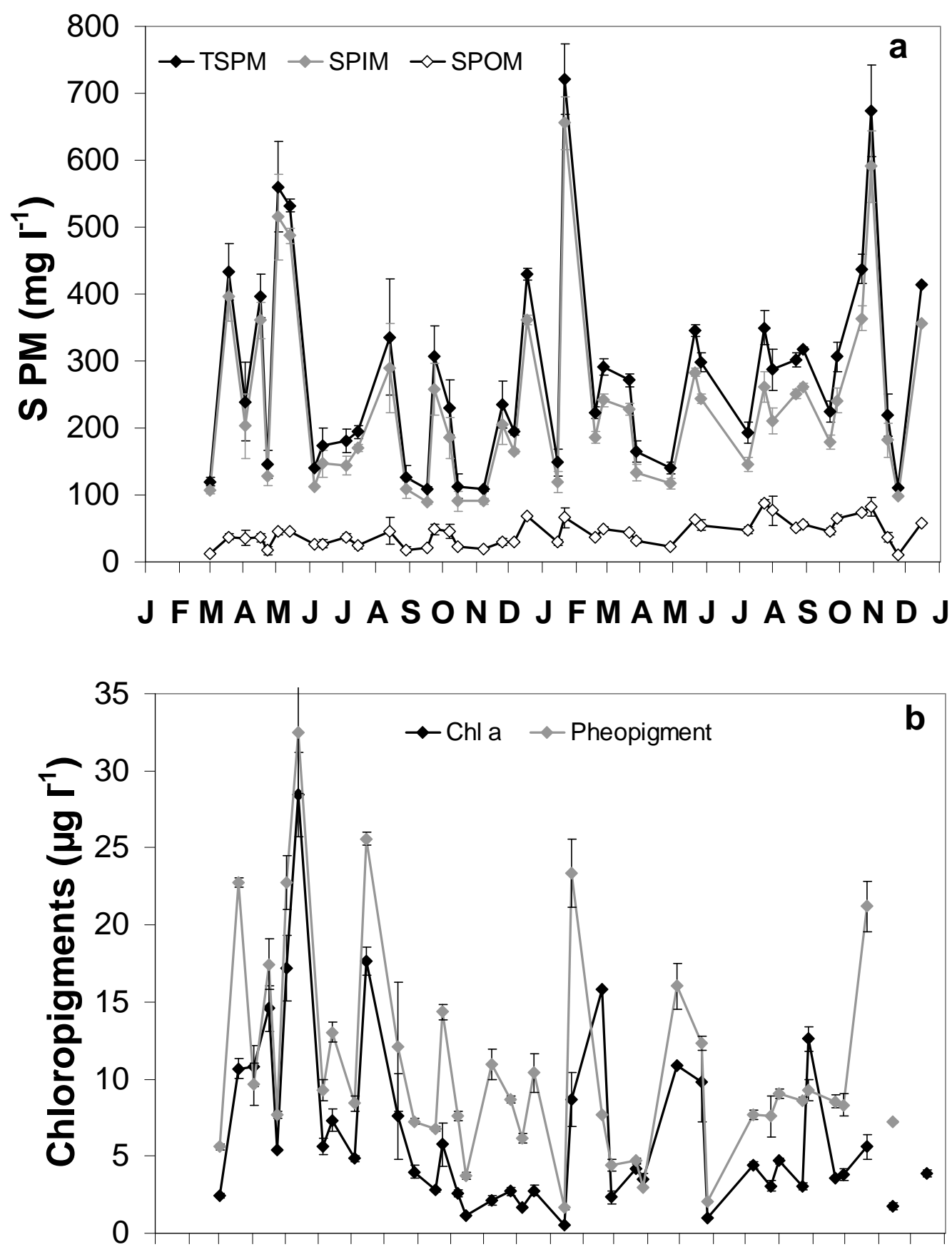

J FMAM J J A SOND J FMAM J J A SOND J

Figure 3. Temporal variation of suspended particulate matter (SPM) at Ronce-les-Bains mudflat from March 2002 to December 2003: (a) total suspended particulate matter (TSPM: •), suspended inorganic particulate matter (SPIM: $\bullet$ ) and suspended particulate organic matter (SPOM: $\diamond)\left(\mathrm{mg} \mathrm{l}^{-1}\right)$; (b) Chlorophyll- a $(\bullet)$ and pheopigments $\left({ }^{\bullet}\right)\left(\mu \mathrm{gl}^{-1}\right)$. Fortnightly spring tides indicated by vertical bars. 


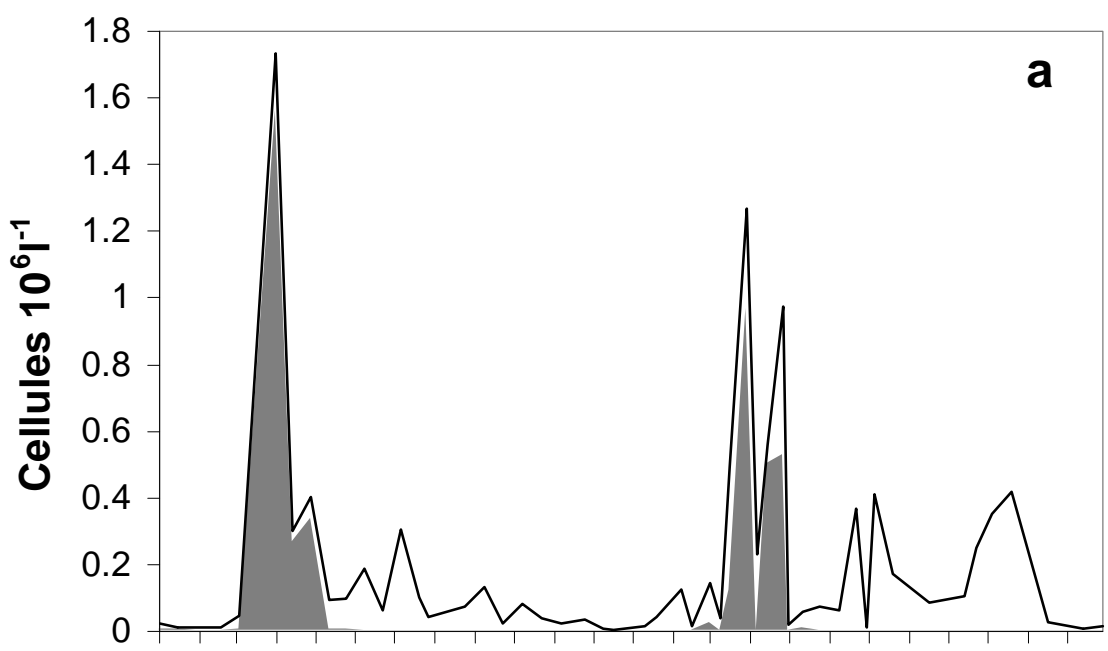

J F M A M J J S O N D J F M A J J A S O N D
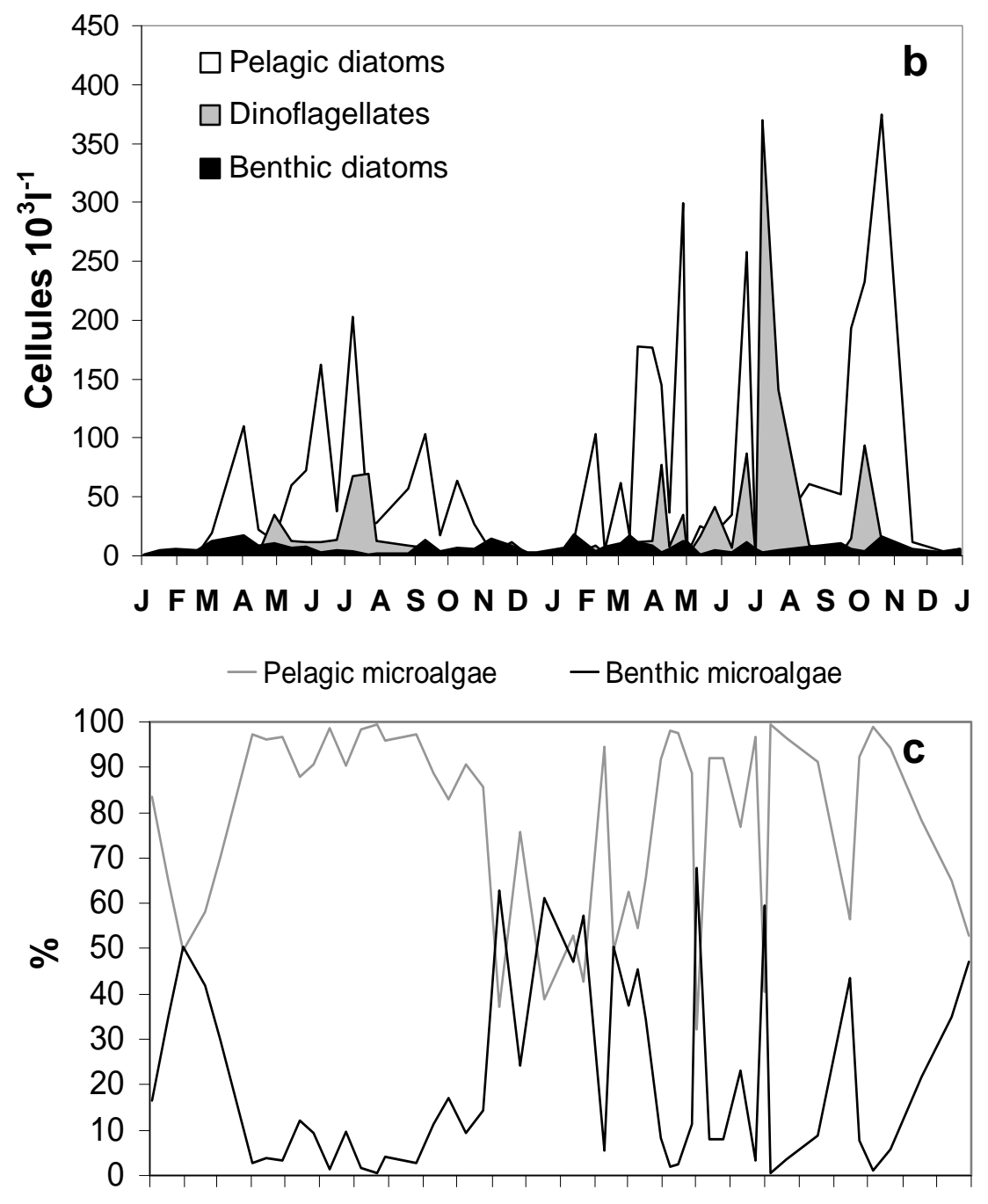

J F MAM J J ASOND J FMAM J J A SOND J

Figure 4. Temporal variation of phytoplankton community at Auger (REPHY) station from January 2002 to December 2003: (a) phytoplankton biomass with Skeletonema costatum diatoms (black striped), (b) classification of phytoplankton biomass except Skeletonema costatum), (c) contribution of 
pelagic (grey line) and benthic (black line) microalgae to phytoplankton biomass. Data are presented with different scales on the $\mathrm{X}$-axis.
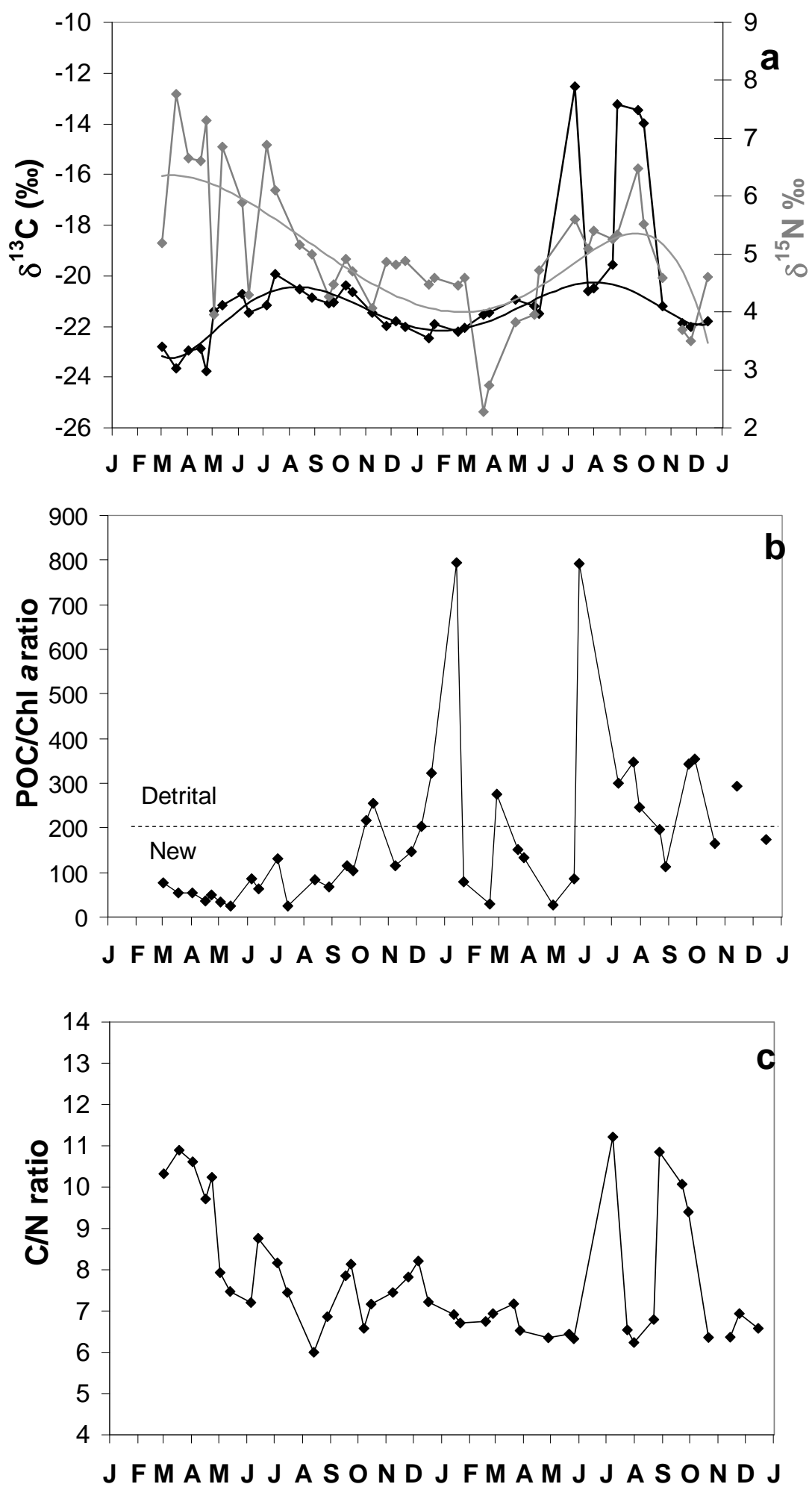

Figure 5. Temporal variation of suspended particulate organic matter (SPOM) at Ronce-les-Bains mud flat from March 2002 to December 2003, with (a) $\delta^{13} \mathrm{C}(\%)(\bullet)$ and $\delta^{15} \mathrm{~N}(\%)(\diamond)$; (b) POC:Chl a ratio with a borderline (dotted line) at 200 (explanation given in text); (c) $\mathrm{C} / \mathrm{N}$ ratio. Polynomial regressions indicated the temporal evolution trend for $\delta^{13} \mathrm{C}$ (black line) $(r=0.88, p<0.001, n=37)$ and $\delta^{15} \mathrm{~N}$ (grey line) $(r=0.69, \mathrm{p}<0.01, \mathrm{n}=41)$ for both years. 


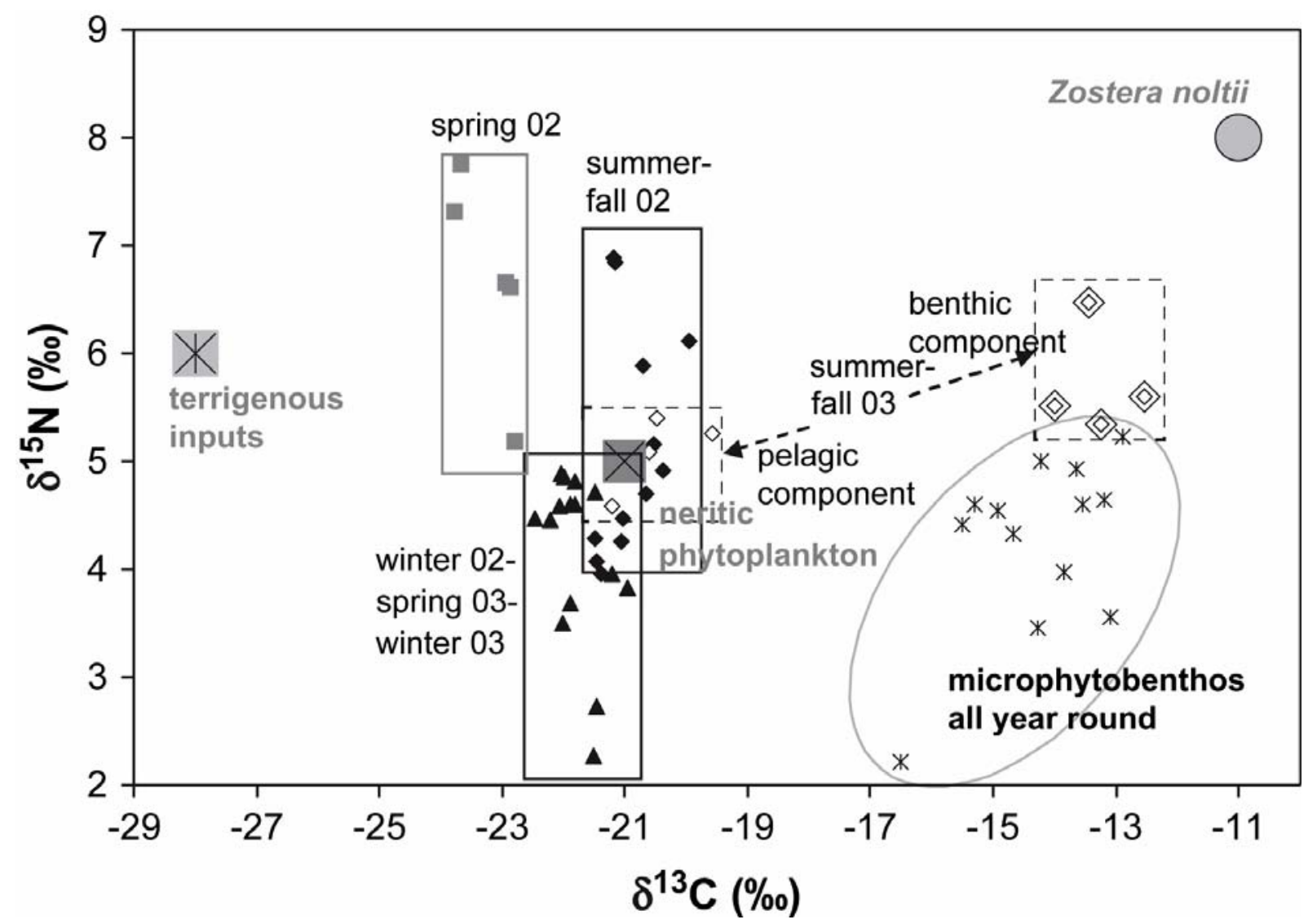

Figure 6. Scatter plot of $\delta^{13} \mathrm{C} \%$ vs $\delta^{15} \mathrm{~N} \%$ of SPOM at Ronce-les-Bains mudflat (data from this study): spring $02 \boxminus$, summer-fall $02 \bullet$, winter 02-spring 03-winter $03 \boldsymbol{\Delta}$, summer-fall 03: $\diamond$, and isotopic composition of neritic phytoplankton: $X$, microphytobenthos: $*$, (data from this study), continental inputs: (Richard et al. 1997), Zostera noltii: (Kang et al., 1999; Boschker et al., 2000). The arrow links pelagic and benthic components sampled at the same period in summer-fall 2003 and encircled diamonds $\diamond$ underline the more higher enriched ${ }^{13} \mathrm{C}$ isotopic values.

Figure 4 